https://helda.helsinki.fi

\title{
Krooninen migreeni
}

\author{
Artto, Ville
}

2019

Artto , V \& Kallela , M 2019 , ' Krooninen migreeni ' , Duodecim , Vuosikerta. 135, Nro 15 , Sivut 1337-1344 . < https://www.duodecimlehti.fi/api/pdf/duo15041 >

http://hdl.handle.net/10138/320919

publishedVersion

Downloaded from Helda, University of Helsinki institutional repository.

This is an electronic reprint of the original article.

This reprint may differ from the original in pagination and typographic detail.

Please cite the original version. 


\section{Krooninen migreeni}

Krooninen migreeni on migreenin harvinainen ja hankala ääripää. Sille on tyypillistä lähes jatkuva päänsärky. Tilanne on täysin erilainen kuin satunnaisesti iskevässä kohtauksittaisessa migreenissä. Kroonisen migreenin hoidon kulmakiviä ovat estolääkitys, altistavien tekijöiden välttäminen ja kohtauslääkkeiden harkittu mutta rajattu käyttö. Kohtauslääkkeiden riskirajana särkylääkepäänsärkyä ajatellen pidetään kahta tai kolmea lääkepäivää viikossa. Tavanomaisista migreenin estolääkkeistä topiramaatti ja botuliinitoksiini ovat osoittaneet tehonsa myös kroonisen migreenin hoidossa. Tärkeää on, että estohoidon punainen lanka säilyy kuukausien, jopa vuosien ajan. Ensimmäiset nimenomaan migreenin estolääkkeiksi kehitetyt vasta-aineet ovat tulossa myös kroonisen migreenin hoitoon. Migreenin hoidossa ollaankin siirtymässä sattumasta perusmekanismeihin perustuvaan täsmäestoon.

M igreeni on monien vastakohtien, ristiriitaisuuksien ja väärinymmärrysten sairaus. Yksittäinen migreenikohtaus on onneksi tunnettu, tunnustettu ja usein kohtuullisen helppohoitoinen. Satunnaiset migreenikohtaukset eivät ole merkittävä uhka toiminta- tai työkyvylle, mutta kroonistuessaan migreeni voi villiintyä päivittäin toistuvaksi vitsaukseksi. Migreenin kroonistuessa elimistö, mielestä puhumattakaan, ei missään vaiheessa palaudu normaalitilaan ennen seuraavaa kovaa oirejaksoa. Jatkuva huono olo ja lääkkeiden haitat ahdistavat, masentavat ja väsyttävät. Vaikka kroonisen migreenin kaltainen ilmiö on tunnettu pitkään, on sen määritelmä ollut kauan vakiintumaton. Tämänkin takia kroonisesta migreenistä ja sen hoidosta on paljon vähemmän tutkimustietoa kuin tavallisesta kohtauksittaisesta (episodisesta) migreenistä. Yleensä yksittäinen kohtaus kannattaa hoitaa mahdollisimman pian tehokkaalla ja nopeasti vaikuttavalla lääkkeellä, mutta tiheään toistuvassa kroonisessa migreenissä sama metodi saattaa johtaa särkylääkepäänsärkyyn ja tilanteen vaikeutumiseen entisestään. Onneksi tulevaisuus näyttää valoisammalta. Kroonisen ja episodisen migreenin kliininen ero alkaa olla jo paremmin tunnettu ja uusia lääkkeitäkin alkaa olla näköpiirissä. Tästä hyötyvät kaikki asianosaiset.

\section{Määritelmä ja epidemiologiaa}

Migreeniä nimitetään krooniseksi, jos päänsärkypäiviä esiintyy kuukausittain enemmän kuin päänsäryttömiä vähintään kolmen kuukauden ajan (тАULUкко 1) (1). Lisäksi migreenin kriteerit täyttäviä päiviä on kuukaudessa oltava vähintään kahdeksan (1). Tyypillisesti potilailla on noin 20-22 päänsärkypäivää kuukaudessa. Kroonista migreeniä sairastaa vain pieni osa migreenipotilaista (noin $8 \%$ ), ja väestötasolla esiintyvyys on 1-2\% (2). Kuten muissakin migreenin muodoissa, myös krooninen migreeni on naisilla tavallisempaa kuin miehillä ja esiintyvyys on suurimmillaan 18-49-vuotiailla naisilla (3). Vuosittain episodinen migreeni kroonistuu noin 2,5-3\%:lla potilaista (4). Usein episodinen migreeni hankaloituu pikkuhiljaa vuosien aikana: kohtaustiheys kasvaa asteittain niin, että päänsärkypäiviä alkaa olla enemmän kuin päänsäryttömiä. Kroonisen migreenin ennuste on sikäli huono, että kahden vuoden seurannassa vain $26 \%$ potilaista toipuu, eli päänsärkypäivien määrä vähenee alle kymmeneen kuukaudessa (5).

Toistuvat päänsärkykohtaukset hallitsevat luonnollisesti potilaiden taudinkuvaa, mutta elämää hankaloittavat myös muut migreeniin liittyvät oireet, joita ovat pahoinvointi, aisti- 
TAULUKKO 1. Kroonisen migreenin ICHD-3-kriteerit (1).

\begin{tabular}{c|l} 
A & $\begin{array}{l}\text { Päänsärkyä (tensio- tai migreenityyppistä) on ainakin } \\
15 \text { päivänä kuukaudessa ainakin kolmen kuukauden } \\
\text { ajan. Kriteerit B ja C täyttyvät. }\end{array}$ \\
\hline B & $\begin{array}{l}\text { Potilaalla on ollut ainakin viisi kohtausta, jotka täyt- } \\
\text { tävät joko } \\
\text { aurattoman migreenin kriteerit tai } \\
\text { aurallisen migreenin kriteerit }\end{array}$ \\
\hline C & $\begin{array}{l}\text { Päänsärky on täyttänyt ainakin kahdeksana päivänä } \\
\text { kuukaudessa yli kolmen kuukauden ajan ainakin } \\
\text { yhden seuraavista piirteistä } \\
\text { aurattoman migreenin kriteerit } \\
\text { aurallisen migreenin kriteerit } \\
\text { potilas uskoo kohtauksen alussa kyseessä olevan } \\
\text { migreenin ja se reagoi triptaani- tai ergotamiini- } \\
\text { lääkitykseen }\end{array}$ \\
\hline D & $\begin{array}{l}\text { Potilaan oireet eivät selity paremmin muulla ICHD- } \\
\text { 3-diagnoosilla }\end{array}$
\end{tabular}

ICHD = The International Classification of Headache Disorders, IHS = International Headache Society, https://www.ichd-3.org

${ }^{1}$ Ergotamiinit eivät ole Suomessa enää käytössä, eivätkä kuulu Käypä hoito -suositukseen

yliherkkyys, kognitiiviset vaikeudet, huimaus ja väsymys. Myös masennus, ahdistus ja seuraavan kohtauksen pelko saattavat lamaannuttaa potilasta. Toimintakyvyn heikentyminen hankaloittaa päivittäistä elämää niin töissä, kotona kuin harrastuksissakin. Tilannetta voi hankaloittaa myös ympäristön asenteellisuus ja ongelman vähättely. Lisäksi migreenin hoitoon käytettävien lääkkeiden aiheuttamat haitat, kuten väsymys, painon nousu, muistivaikeudet ja huimaus, saattavat vaikeuttaa tilannetta entisestään.

\section{Särkylääkepäänsärky}

Migreenin kroonistuminen on vielä puutteellisesti tunnettu ilmiö. Tunnetuista ja vaikutettavissa olevista riskitekijöistä kohtauslääkkeiden liiallinen käyttö lienee olennaisin (6). Tyypillisesti useita kuukausia jatkunut liian runsas kohtauslääkkeiden käyttö voi johtaa särkylääkepäänsärkyyn, jolloin lääkkeiden käyttö pitää yllä jatkuvaa päänsärkyä. On ilmeistä, että eri ihmisillä on hyvin erilainen taipumus särkylääkepäänsäryn kehittymiseen, mutta ajatellaan, että tulehduskipulääkkeitä ei pitäisi käyttää enempää kuin 15 päivänä kuukaudessa. Vastaava luku triptaaneilla on kymmenen päivää. Olennaisinta on, kuinka tiuhaan potilas käyttää kohtauslääkkeitä kaiken kaikkiaan. Keskimäärin selvästi yli puolet viikon päivistä tulisi olla kohtauslääkkeettömiä. Erityisen petollisia särkylääkepäänsäryn kannalta ovat opioidit, joita tulisi välttää migreenin hoidossa.

Särkylääkepäänsäryn ehkäisy on keskeistä. Potilaiden, terveydenhoitoalan ammattilaisten ja apteekkihenkilökunnan olisi hyvä tiedostaa ilmiö mahdollisimman hyvin, koska tilanteeseen on helpompi puuttua siinä vaiheessa, kun kipu- ja lääkekierre ei ole vielä kehittynyt liian hankalaksi. Yksittäisen potilaan kohdalla ei kuitenkaan ole aina helppo sanoa, onko liiallinen kohtauslääkkeiden käyttö ennemmin jatkuvan päänsäryn syy vai seuraus. On myös esitetty kriittisiä kommentteja koko ilmiön olemassaolosta ja merkityksestä (7).

Särkylääkepäänsäryn tunnistamisessa ja myös hoitovasteen arvioinnissa päänsärkypäiväkirja on hyvä työkalu, kunhan potilaat merkitsevät särkypäivien lisäksi huolellisesti myös käyttämänsä kohtauslääkkeet ja muut mahdolliset altisteet. Särkylääkepäänsäryn hoidossa ensimmäinen askel on tyypillisesti potilaan informointi, joka jo saattaa johtaa päänsärkypäivien vähenemiseen (8). Jos tämä osoittautuu riittämättömäksi, tehostetaan hoitoa joko kohtauslääkevieroituksella tai estolääkityksen aloituksella. Edelleenkin on kiistanalaista, missä järjestyksessä näiden toimenpiteiden suhteen tulisi edetä. Lisäksi lääkevieroituksen optimaalisesta kestosta ja muusta toteutuksesta ei ole näyttöön perustuvaa konsensusta. Lääkevieroitus tulee suunnitella potilaskohtaisesti ja ottaa huomioon särkylääkepäänsäryn kesto sekä vaikeus. Joka tapauksessa kaikista kohtauslääkkeistä tulisi yleensä pidättäytyä vieroituksessa viikkoja, mutta joidenkin keskusten käytäntönä on jopa kuukausia kestävä vieroitus (9). Hankalassa opioidikierteessä lääkkeiden äkillinen lopettaminen ei yleensä ole realistista, vaan lääkitys puretaan asteittain. Lääkevieroitus toteutetaan yleensä avohoidossa, mutta joskus se joudutaan tekemään vuodeosastolla. Avohoidossa tai osastolla tehtyjä lääkevieroituksia vertailevissa pienehköissä tutkimuksissa 
ei ole saatu eroja hoitomuotojen välille (10). Pahoinvointilääkkeitä voidaan käyttää lääkevieroituksen yhteydessä oireiden lievittämiseen. Glukokortikoidikuurin merkitys on kiistanalainen, mutta joillekin potilaille merkittävän avun tuova lisä. Lähes puolella potilaista krooninen migreeni helpottuu episodiseksi migreeniksi lääkevieroituksen myötä (11), mutta joidenkin potilaiden kohdalla parempi tilanne jää tilapäiseksi ja lääkevieroitus joudutaan toistamaan aika ajoin.

\section{Migreenin kroonistumisen muut riskitekijät}

Kohtauslääkkeiden liiallisen käytön vastakohta, mutta yhtä lailla kroonistumiselle altistava tekijä on yksittäisten kohtausten puutteellinen hoito. Tämä tarkoittaa liian pientä annosta tai myöhään otettua kohtauslääkettä, jolloin usein toistuva pitkittyvä migreenisärky saattaa johtaa aivojen kipualueiden herkistymiseen ja sen myötä altistaa migreenin kroonistumiselle (12). Tämän ilmiön ja toisaalta särkylääkepäänsäryn riskin takia potilaan ohjeistaminen omien oireiden tunnistamiseen ja oikeanlaiseen kohtausten hoitoon on keskeistä mutta ei helppoa, koska ohjeet ovat keskenään osin ristiriitaisia. Potilaan tulisi tunnistaa migreenikohtaus, johon hän tarvitsee joka tapauksessa kohtauslääkitystä ja osata hoitaa kohtaus riittävän tehokkaasti. Huonoin vaihtoehto on, että potilas toistuvasti kärvistelee koko päivän ilman kohtauslääkitystä särkylääkepäänsäryn pelossa, mutta lopulta ottaa lääkkeet päivän päätteeksi, jolloin hän saattaa altistua sekä pitkittyvälle särylle että kohtauslääkkeiden liikakäytölle.

Psyykkiset tekijät kuten masennus, ahdistus ja tietyt persoonallisuuden piirteet lisäävät migreenin kroonistumisen riskiä (13). Toisaalta yhteys on usein molemminpuolinen, eli hankala migreenioireisto saattaa myös heikentää mielialaa ja aiheuttaa muutenkin psyykkisiä ongelmia. Myös stressi ja kuormittavat elämäntilanteet lisäävät migreenin kroonistumisen riskiä.

Ylipainon ja metabolisen oireyhtymän tiedetään myös lisäävän migreenin kroonistumisen riskiä (14). Ilmiö tunnetaan huonosti, mutta se saattaa liittyä insuliiniresistenssiin, hyperlepti-

\section{Ydinasiat}

" Krooninen ja episodinen migreeni ovat saman taudin erilaiset ääripäät.

n Kroonisessa migreenissä korostuu estohoito, episodisessa migreenissä kohtaushoito.

\ Krooninen migreeni kehittyy lähes aina episodisesta migreenistä, mikä korostaa anamneesin tärkeyttä diagnostiikassa.

" Kroonistumiseen voi johtaa sekä tehoton että liiallinen kohtauslääkkeiden käyttö. Särkylääkepäänsärky on käytännössä tärkein riskitekijä.

\Päänsärkypäiväkirja on erinomainen apuväline diagnostiikassa ja hoitovasteen seurannassa.

\ Päänsärky- ja kohtauslääkepäivät, kuten myös täysin terveet päivät, ovat hyviä seurantamuuttujia.

nemiaan tai ylipainon ylläpitämään jatkuvaan tulehdustilaan. Toisaalta ylipainoisilla kroonisesta päänsärystä kärsivillä potilailla tulee pitää mielessä myös idiopaattisen intrakraniaalisen hypertension (IIH) mahdollisuus ja herkästi harkittava selkäydinnesteen avauspaineen mittausta erotusdiagnostisessa mielessä.

Muut kipua aiheuttavat ja kipulääkkeiden käyttöä lisäävät sairaudet lisäävät myös migreenin kroonistumisen riskiä. Erityisen hankalaa onkin saada hyviä hoitotuloksia potilailla, joilla särkylääkepäänsärky kroonistaa migreeniä ja joilla on samalla esimerkiksi tuki- ja liikuntaelinsairausvaivoja, jonka myötä särkyläk̈keiden käytön rajoittaminen voi olla epärealistista. Tällöin kroonisen kivun hoitaminen kipukynnystä nostavilla lääkkeillä (esimerkiksi amitriptyliini, nortriptyliini tai gabapentiini) saattaa vähentää särkylääkkeiden tarvetta. Päähän kohdistunut vamma lisää myös migreenin kroonistumisen riskiä, kuten myös purentaelimistön toimintahäiriöt, yöllinen hampaiden narskuttelu, kuorsaaminen ja liikunnan harrastamattomuus (15). Migreenin kroonistumisen on lisäksi todettu olevan todennäköisempää naisilla ja vähemmän koulutetuilla (16). 
TAULUKKO 2. Kroonisen migreenin patofysiologia.

\begin{tabular}{|c|c|c|}
\hline $\begin{array}{l}\text { Migreenin kroonistu- } \\
\text { misen mekanismit }\end{array}$ & Välittävä rakenne & Huomio \\
\hline \multirow[t]{3}{*}{$\begin{array}{l}\text { Perifeerinen } \\
\text { sensitisaatio }\end{array}$} & $\begin{array}{l}\text { Aivokalvojen ja pään alueen veri- } \\
\text { suonten kipusäikeet (C-säikeet) }\end{array}$ & $\begin{array}{l}\text { C-säikeet tuottavat kipuimpulsseja paikallisesti vapautuvien } \\
\text { välittäjäaineiden (kuten CGRP, NO ja PACAP) vaikutuksesta. }\end{array}$ \\
\hline & $\begin{array}{l}\text { Kipuradan ensimmäinen hermo- } \\
\text { solu kolmoishermon gangliossa } \\
\text { ja ympäröivä tukisolukko (radial } \\
\text { glia) }\end{array}$ & $\begin{array}{l}\text { Trigeminusganglion hermosolut (C-säikeiden soomaosat) ja } \\
\text { niitä ympäröivät gliasolut saavat aikaan kipua ylläpitävän } \\
\text { noidankehän, jossa CGRP on keskeinen välittäjäaine. }\end{array}$ \\
\hline & $\begin{array}{l}\text { Ganglion hermosoluja ympäröivä } \\
\text { tukisolukko (radial glia) }\end{array}$ & $\begin{array}{l}\text { Perifeerinen sensitisaatio herkistää kaikelle sensoriselle infor- } \\
\text { maatiolle - seurauksena on valo-, ääni-, haju- ja liikearkuus. }\end{array}$ \\
\hline \multirow[t]{5}{*}{$\begin{array}{l}\text { Sentraalinen } \\
\text { sensitisaatio }\end{array}$} & $\begin{array}{l}\text { Kipuradan toinen hermosolu } \\
\text { trigeminuksen aivorunko- } \\
\text { tumakkeessa }\end{array}$ & $\begin{array}{l}\text { Jatkuva kipu aktivoi trigeminuksen aivorunkotumakkeen. } \\
\text { Koko kipujärjestelmä herkistyy ja alkaa reagoida aiempaa } \\
\text { herkemmin periferiasta saapuviin impulsseihin. }\end{array}$ \\
\hline & $\begin{array}{l}\text { Kipu- ja sensoristen ratojen } \\
\text { keskushermostoyhteydet }\end{array}$ & $\begin{array}{l}\text { Aivorungon suojaavat mekanismit pettävät. Aistiarkuus vaikeu- } \\
\text { tuu. Herkistymä kipuradassa johtaa allodyniaan - tavallinen } \\
\text { kosketus pään alueella tekee kipeää. }\end{array}$ \\
\hline & $\begin{array}{l}\text { C1-2-hermojuuret keskus- } \\
\text { hermostoyhteyksineen }\end{array}$ & $\begin{array}{l}\text { Trigeminushermon aivorunkotumake jatkuu kaulaytimen } \\
\text { puolelle (trigeminokervikaalinen kompleksi). Herkistymisilmiö } \\
\text { laajenee niskan alueelle. }\end{array}$ \\
\hline & $\begin{array}{l}\text { Kipuradan kolmas hermosolu } \\
\text { talamuksessa }\end{array}$ & $\begin{array}{l}\text { Toistuvat kipukohtaukset herkistävät myös kipuradan seuraa- } \\
\text { van tumakkeen, talamuksen. Allodyniaa alkaa esiintyä ympäri } \\
\text { kehoa, ei pelkästään paikallisesti pään ja niskan alueella. }\end{array}$ \\
\hline & Aivokuori (cortex) & $\begin{array}{l}\text { Vuosia kestävä päänsärkyongelma muuttaa aivokuoren (sen- } \\
\text { sorinen aivokuori), otsalohkon, mantelitumakkeen (amygdala) } \\
\text { ja aivosaaren (insula) toimintaa. Kivusta vastaava hermoverkko } \\
\text { herkistyy koko matkallaan periferiasta aivokuorelle. }\end{array}$ \\
\hline $\begin{array}{l}\text { Kohtauslääkkeiden } \\
\text { kroonistava vaikutus }\end{array}$ & $\begin{array}{l}\text { Trigeminusganglio, aivorungon } \\
\text { kipua estävät laskevat radat }\end{array}$ & $\begin{array}{l}\text { Kohtauslääkkeiden liikakäyttö lisää kohtausfrekvenssiä tunte- } \\
\text { mattomasta syystä - taustalla saattaa olla noidankehä trige- } \\
\text { minusgangliossa ja kivulta suojaavien aivorunkomekanismien } \\
\text { pettäminen. }\end{array}$ \\
\hline $\begin{array}{l}\text { Alttius migreenin } \\
\text { kroonistumiselle }\end{array}$ & $\begin{array}{l}\text { Perinnöllinen tai hankinnainen } \\
\text { herkkyys kivun kroonistumiselle }\end{array}$ & $\begin{array}{l}\text { Kroonistumisen alttiusgeenit ovat vielä tuntemattomia. } \\
\text { Lukuisia molekyyli- ja epigeneettisiä tutkimuksia on meneillään } \\
\text { asian selvittämiseksi. Puolet migreeneistä on arvioitu liittyvän } \\
\text { geeneihin, puolet ympäristötekijöihin. }\end{array}$ \\
\hline
\end{tabular}

CGRP = Calcitonin gene related peptide, NO = typpioksidi, PACAP = Pituitary adenylate-cyclase-activating polypeptide, epigeneettinen periytyminen = perinnöllisen tiedon siirto solun tai eliön jälkeläiselle ilman, että se on koodattuna DNA:n tai RNA:n sekvenssiin

\section{Kroonisen migreenin patofysiologia}

Miksi migreenikohtaus alkaa, tai kohtaus loppuu, on edelleen mysteeri. Itse pääkipuun ja sen liitännäisoireisiin liittyvät mekanismit tunnetaan kuitenkin melko hyvin sekä episodisen että kroonisen migreenin suhteen (TAULUKко 2). Kroonisen migreenin taustalla on koko sensorisen järjestelmän yleinen säätelyhäiriö, eli perifeerinen ja sentraalinen sensitisaatio (kivulle herkistyminen). Toistuvat päänsärky- kohtaukset valmentavat aistiradat reagoimaan tehokkaasti sekä sisäisiin (hormoni- ja energiapitoisuudet, uni) että ulkoisiin (alkoholi, tietyt ruoat, stressitekijät) provokaattoreihin. Migreenille tyypillinen kipu- ja hajuherkkyys sekä valo-, ääni- ja liikearkuus ovat näiden herkistymisilmiöiden kliinisiä piirteitä. Kipuherkkyyttä kutsutaan myös allodyniaksi, jossa normaalisti kivuttomat ärsykkeet aistitaan kipuna. Lopulta ylikierroksilla käyvät aistiradat saavat aikaan sen, että päänsärkypäiviä on enemmän kuin säryttömiä. 
TAULUKKO 3. Migreenin estohoitoon käytettäviä valmisteita.

\begin{tabular}{|c|c|c|}
\hline Migreenin estohoitolääke & Esimerkki & $\begin{array}{l}\text { Migreenipäivien tai päänsärkypäivien } \\
\text { vähenemä kuukaudessa }\end{array}$ \\
\hline Beetasalpaajat & Propranololi, metoprololi & $0,4^{1}$ \\
\hline $\begin{array}{l}\text { Angiotensiini II -reseptorin } \\
\text { salpaajat }\end{array}$ & Kandesartaani & $0,6-1,1^{1}$ \\
\hline Trisykliset masennuslääkkeet & Amitriptyliini, nortriptyliini & Ei tietoa migreenipäivien vähenemisestä \\
\hline \multirow[t]{2}{*}{$\begin{array}{l}\text { Neuromodulaattorit (epilepsia- } \\
\text { lääkkeet) }\end{array}$} & Topiramaatti & $\begin{array}{l}\text { Episodinen migreeni } 1,1-1,3 \\
\text { Krooninen migreeni } 1,5-3,3\end{array}$ \\
\hline & Valproaatti & $2,6^{1}$ \\
\hline Botuliinitoksiini & Botuliinitoksiini & Krooninen migreeni $1,5-2,4$ \\
\hline CGRP:n vasta-aineet & $\begin{array}{l}\text { Eptinetsumabi, erenumabi, frema- } \\
\text { netsumabi, galkanetsumabi }\end{array}$ & $\begin{array}{l}\text { Episodinen migreeni } 1,0-2,8 \\
\text { Krooninen migreeni } 2,5\end{array}$ \\
\hline Itsehoitovalmisteet & $\begin{array}{l}\text { Koentsyymi Q10, magnesium, melato- } \\
\text { niini, ruttojuurivalmisteet, riboflaviini }\end{array}$ & $0,5-1,1^{1}$ \\
\hline
\end{tabular}

${ }^{1}$ Tutkimuksissa ei ole analysoitu erikseen episodista ja kroonista migreeniä CGRP $=$ Calcitonin gene related peptide

\section{Tutkimukset ja erotusdiagnostiikka}

Kroonisen migreenin diagnostiikassa potilaan huolellinen haastattelu on avainasemassa, ja konetutkimuksilla on merkitystä vain poissulkumielessä. Neurologisen statuksen tulisi olla normaali tai poikkeaville löydöksille löytyä selitys. Kliinisessä tutkimisessa arvioidaan myös niska-hartiaseudun lihaksistoa ja purentaelimistöä, jotta näiden häiriöihin liittyvät ongelmat huomattaisiin. Tarvittaessa potilas ohjataan hammaslääkärin tai purentafysiologin arvioon. Migreenin kroonistuttua oireisto on usein vyyhtiytynyt, jolloin oikeaan diagnoosiin pääsemiseksi saattaa olla tarpeen käydä läpi, minkälaisia kohtaukset olivat ennen tilanteen komplisoitumista. Osalla potilaista oireistossa saattaa olla myös piirteitä muista päänsärkysairauksista, kuten sarjoittaisesta päänsärystä, mikä tulee huomioida hoitoja suunniteltaessa. Kroonistuneen päänsäryn taustalla on vain harvoin vakavampia syitä, kuten aivojen laskimotukos (sinustromboosi) tai kasvain, mutta mahdolliset vaaranmerkit on syytä tunnistaa (17).

Päänsärkypäiväkirja on hyödyllinen työkalu särkylääkepäänsäryn ja muiden altistavien tekijöiden tunnistamisessa mutta myös migreenin aktiivisuuden ja hoitovasteen arvioinnissa. Päiväkirjassa olisi hyvä erotella yksittäisissä päänsärkypäivissä myös se, onko kyse lievemmästä, voimakkaammasta vai täysin lamaannuttavasta oireistosta. Lisäksi päiväkirjaan olisi hyvä merkitä esimerkiksi kuukautiset, käytetyt kohtauslääkkeet ja aloitetut estohoidot sekä mahdolliset päivystyskäyntiin johtaneet migreenikohtaukset.

\section{Kroonisen migreenin hoito}

Kroonisen migreenin hoidon kulmakiviä ovat altistavien tekijöiden eliminoiminen ja migreenin aktiivisuutta vähentävät hoidot (TAULUкко з). Valitettavasti nykyisillä hoidoilla hyvään tulokseen pääseminen osoittautuu usein hankalaksi. Migreenin kroonistumisen riskitekijöitä, esimerkiksi masennusta ja ylipainoa tulisi kartoittaa ja pyrkiä puuttumaan niihin. Tutkimustietoa masennuksen tai ylipainon hoidon vaikutuksista krooniseen migreeniin ei ole, mutta esimerkiksi episodisen migreenin on raportoitu lievittyvän lihavuusleikkauksen jälkeen $(18,19)$. Ylipainoisen kannustaminen laihduttamiseen on luonnollisesti perusteltua myös elämänlaadun parantamisen ja muun terveyden kannalta.

Episodisen migreenin estolääkityksistä vain topiramaatista on osoitettu olevan hyötyä myös kroonisen migreenin hoidossa lumekontrolloiduissa tutkimuksissa (тAULUкKо 3). Topiramaatti aloitetaan annoksella $25 \mathrm{mg} 1 \times 1$, ja 
vuorokausiannosta suurennetaan asteittain kahden viikon välein tavoitteena annos $50 \mathrm{mg}$ $1 \times 2$ (20). Sopiva annostus on yksilöllistä. Topiramaatin teho on kohtalainen, mutta haittavaikutukset (esimerkiksi ihon pistely tai puutuminen, ruokahaluttomuus ja kognitiiviset ongelmat) ovat usein esteenä lääkkeen käytölle. Lisäksi se saattaa heikentää mielialaa, joten topiramaatin käyttöä tulisi välttää potilailla, joilla on masennustaipumusta. Myös muita episodisen migreenin estolääkityksiä, kuten ami- tai nortriptyliiniä, kandesartaania tai beetasalpaajia voi kokeilla kroonisen migreenin hoidoksi.

Botuliinitoksiinin (TAULUкKо 3) suotuisista vaikutuksista päänsärkyihin on havaintoja vuosikymmenien ajalta, mutta tutkimuksissa se osoittautui tehottomaksi episodisen migreenin ja tensionaalisen päänsäryn hoitona. Näiden negatiivisten tutkimusten jälkeen päädyttiin kuitenkin lumekontrolloituun tutkimukseen, johon otettiin yli tuhat kroonista migreeniä sairastavaa potilasta. Hoitoryhmän potilaille pistettiin 155-195 yksikköä (31-39 pistosta) botuliinitoksiinia otsan, ohimoiden ja niskahartiaseudun alueille kolmen kuukauden välein (21). Lähtötilanteessa botuliinitoksiiniryhmään arvotuilla potilailla oli kuukaudessa 19,9 ja lumeryhmäläisillä 19,8 päänsärkypäivää. Vastetta arvioitiin viikolla 24, jolloin hoitoryhmässä olevilla potilailla kuukausittaisten päänsärkypäivien määrä oli vähentynyt keskimäärin 8,4:1lä ja vastaavasti lumeryhmässä 6,6 päivällä. Ero ryhmien välillä oli tilastollisesti merkitsevä, vaikka lumeryhmässäkin tilanne kohentui huomattavasti lähtötilanteesta. Huomionarvoista on, että botuliinitoksiinihoidosta hyötyivät yhtä lailla myös ne potilaat, joilla todettiin hoidon alkaessa kroonisen migreenin lisäksi särkylääkepäänsärky.

Botuliinitoksiinin vaikutusmekanismi kroonisessa migreenissä on kiistanalainen asia. Yleisimmin suotuisan vaikutuksen ajatellaan tulevan perifeeristen trigeminaalisten neuropeptidien vapautumisen estosta, mutta osa tutkijoista ajattelee vaikutuksen tulevan myös sentraalisesti. Julkisen terveydenhuollon puolella hoitokäytännöt vaihtelevat eri sairaanhoitopiireissä. Osassa botuliinitoksiinihoitoa tarjotaan vain kokeilumielessä kaksi kertaa, kun taas toisissa keskuksissa hoitoa voidaan toteuttaa pidempään. Botuliinitoksiinilla on nykyisin myös peruskorvattavuus kroonisen migreenin hoidossa.

Lääkehoitojen lisäksi kajoamattomilla neuromodulaatiohoidoilla on saatu alustavasti lupauksia herättäviä tuloksia ainakin okkipitaalihermoon tai vagushermoon kohdistuvan ja toisaalta supraorbitaalisen stimulaation osalta (16). Lisäksi akupunktiolla ja kognitiivisella behavioraalisella terapialla on osoitettu olevan hyötyä kroonisen migreenin hoidossa $(22,23)$. Näissä kaikissa hoitomuodoissa on kuitenkin huomioitava tutkimusten pienehköt koot ja ongelmat lumevertailun toteuttamisessa verrattuna lääkehoitotutkimuksiin. Ainakin osa potilaista saattaa hyötyä myös esimerkiksi fysioterapiasta, hieronnasta tai liikunnasta.

\section{Uudet mahdollisuudet: CGRP:n vasta-aineet kroonisen migreenin hoidossa}

Uudet CGRP:n vasta-aineet (calcitonin gene related peptide) ovat vahvasti tulossa niin tiheästi toistuvan episodisen kuin kroonisen migreeninkin estohoitoon. Kaikki neljä valmistetta tehoavat selvästi ja toistetusti lumetta paremmin ja ovat huomattavasti nykyisiä lääkkeitä paremmin siedettyjä (24). Kokonaisuutena tehoero perinteisiin lääkityksiin on vain kohtalainen (TAULUкKо 3), mutta noin neljäsosa potilaista vaikuttaisi saavan poikkeuksellisen hyvän vasteen, eli 75-100 \%:n vähenemän päänsärkypäivissä. Tällä hetkellä valmisteiden välistä paremmuutta ei voi päätellä, sillä suoria vertailututkimuksia ei ole tehty. Näyttää siltä, että kaikki neljä valmistetta starttaavat suurin piirtein samalta lähtöviivalta. Jokaisen suhteen tarvitaan edelleen pitkäaikaisturvallisuuden seurantaa erityisesti sydän- ja verenkiertoelimistön osalta.

\section{Lopuksi}

Migreeni on perusluonteeltaan vaihteleva sairaus - hyvät ja huonot jaksot vuorottelevat elämän eri vaiheissa. Kun tilanne on hallinnassa, valtaosa potilaista ei tarvitse kohtauslääki- 
TAULUKKO 4. Kroonisesta migreenistä kärsivä potilas vastaanotolla.

\begin{tabular}{|c|c|}
\hline & Huomio \\
\hline Diagnoosin varmistus & Krooninen migreeni kehittyy yleensä vähitellen episodisesta migreenistä. \\
\hline Vaaranmerkkien poissulku & $\begin{array}{l}\text { Tärkeimmät vaaranmerkit ovat selvä muutos aiempiin kohtauksiin verrattuna ja } \\
\text { uudet neurologiset oireet sekä löydökset kuten salpausnysty (staasipapilla). }\end{array}$ \\
\hline Vaikeuden kartoitus & $\begin{array}{l}\text { Päänsärkypäiväkirja on tärkein seurannan väline, tyypillisesti päänsärkypäiviä on } \\
\text { noin } 20 \text { kuukaudessa. }\end{array}$ \\
\hline Päänsärkypäivät kuukaudessa & Yleisin päätemuuttuja lääketutkimuksissa. \\
\hline Oireettomat päivät kuukaudessa & Täysin oireettomien päivien raportointi tuo seurantaan positiivisen vireen. \\
\hline Kohtauslääkepäivät kuukaudessa & Särkylääkepäänsäryn riski suurenee, kun kuukaudessa on yli 10 kohtauslääkepäivää. \\
\hline Päivystyskäynnit kuukaudessa & $\begin{array}{l}\text { Tärkeä ja usein laiminlyöty mittari - kertoo nopeasti ja paljon päänsäryn aiheutta- } \\
\text { masta käytännön haitasta. }\end{array}$ \\
\hline Liitännäissairaudet & $\begin{array}{l}\text { Pyri hoitamaan myös mahdolliset muut krooniset kiputilat, masennus- ja ahdistus- } \\
\text { oireet sekä ylipaino. }\end{array}$ \\
\hline Lääkevieroituksen harkinta & $\begin{array}{l}\text { Kaikkien kohtauslääkkeiden tauotus 2-3 viikon ajaksi. Estolääkityksen aloitus ja } \\
\text { lyhyen glukokortikoidikuurin harkinta. }\end{array}$ \\
\hline $\begin{array}{l}\text { Näyttöön perustuvan esto- } \\
\text { lääkityksen aloitus }\end{array}$ & $\begin{array}{l}\text { Tavanomaiset migreenin estolääkkeet (beetasalpaajat, kandesartaani, ami- tai } \\
\text { nortriptyliini) on yleensä jo kokeiltu migreenin kroonistuessa. }\end{array}$ \\
\hline Botuliinitoksiini & Näyttöön perustuva hoito. Seuranta hoitoprotokollan mukaisesti 3 kuukauden välein. \\
\hline Topiramaatti & $\begin{array}{l}\text { Näyttöön perustuva hoito - tehokas, elleivät haittavaikutukset estä tehokkaan hoito- } \\
\text { annoksen (50-100 mg x 2) saavuttamista. }\end{array}$ \\
\hline CGRP:n vasta-aineet & $\begin{array}{l}\text { Tulossa ja tulleet markkinoille 2018-2019. Tutkimustulokset tehon ja turvallisuuden } \\
\text { suhteen hyvin lupaavia. }\end{array}$ \\
\hline Lääkkeetön hoito & $\begin{array}{l}\text { Kuuluu aina alusta lähtien lääkkeellisen hoidon rinnalle. Harvoin riittävä ainoana } \\
\text { hoitomenetelmänä. Säännöllisen seurannan järjestäminen on osa lääkkeetöntä } \\
\text { hoitoa. }\end{array}$ \\
\hline
\end{tabular}

CGRP $=$ Calcitonin gene related peptide

tyksen lisäksi erityistä apua, mutta kroonistuminen mullistaa tilanteen. Tuolloin migreeni vaikuttaa potilaan päivittäiseen suorituskykyyn niin päänsärkypäivinä kuin muulloinkin. Täysin terveet päivät ovat kortilla, sillä migreenioireita, kuten aistiarkuus ja pahoinvointi, saattaa esiintyä päivittäin, olipa migreenipäänsärkyä tai ei. Tilanne ei ole kuitenkaan mahdoton - toivolle on aina sijaa. Uusia hoitoja on tulossa ja parempi ymmärrys kroonisesta migreenistä parantaa tuloksia lääkehoidon ohella (TAULUKKо 4). Oikea hoitopaikka on keskeinen ja ratkaistavissa oleva ongelma: tarvitaan aikaa, kärsivällisyyttä ja panostusta myös migreeniä ylläpitäviin tekijöihin puuttumiseen, kuten ahdistukseen, masennukseen ja muihin liitännäisongelmiin. Paras hoitopaikka on se, jossa on aikaa ja resursseja paneutua kokonaisvaltaisesti potilaan ongelmiin sekä myös seurata interventioiden tehoa. Krooninen ongelma ei selviä yhdellä hoitokäynnillä. Onneksi uusien lääkkeiden vähäiset haitat parantavat myös po- tilaiden hoitomyöntyvyyttä, jolloin hoitavan lääkärin on helpompi säilyttää punainen lanka, kun migreeni luonteensa mukaisesti aika ajoin vauhkoontuu ilman selvää ulkoista syytä. Migreenialttius kestää koko elämän, se ei ole vain yksittäinen päänsärkykohtaus tai kohtauksien sarja. On aika siirtyä pelkästä kohtaushoidosta tämän alttiuden pitkän aikavälin rauhoittamiseen sekä lääkkeellisin että ei-lääkkeellisin keinoin.

\section{VILLE ARTTO, dosentti, neurologian erikoislääkäri MIKKO KALLELA, dosentti, neurologian erikoislääkäri Hyks, neurologian klinikka, neurokeskus}

\section{VASTUUTOIMITTAJA}

Perttu J. Lindsberg

\section{SIDONNAISUUDET}

Ville Artto: Korvaukset koulutus- ja kongressikuluista (Roche, Sanofi, TEVA), luento-/asiantuntijapalkkio (Novartis,Teva) Mikko Kallela: Apuraha (HUS/HYKS, Helsingin yliopisto), luento-/ asiantuntijapalkkio (Allergan, Bayer, Boehringer-Ingelheim, Genzyme, MSD, Novartis, Pfizer, Sandoz, Exeltis, Teva), korvaukset koulutus- ja kongressikuluista (Allergan, Biogen, Genzyme, Novartis, TEVA), muut sidonnaisuudet (Helsingin Päänsärkykeskus osakeomistus \& hallituksen puheenjohtaja) 


\section{KIRJALLISUUTTA}

1. Headache Classification Committee of the International Headache Society (IHS). The international classification of headache disorders, 3rd edition. Cephalalgia 2018; 38: 1-211.

2. Dodick DW. Migraine. Lancet $2018 ; 391$ : 1315-30.

3. Buse DC, Manack AN, Fanning KM, ym Chronic migraine prevalence, disability, and sociodemographic factors: results from the American migraine prevalence and prevention study. Headache 2012;52: 1456-70.

4. Bigal ME, Serrano D, Buse D, ym. Acute migraine medications and evolution from episodic to chronic migraine: a longitudinal population-based study. Headache 2008;48:1157-68.

5. Manack A, Buse DC, Serrano D, ym. Rates, predictors, and consequences of remission from chronic migraine to episodic migraine. Neurology 2011;76:711-8.

6. Diener HC, Holle D, Solbach K, ym. Medication-overuse headache: risk factors, pathophysiology and management. Nat Rev Neurol 2016;12:575-83.

7. Scher Al, Rizzoli PB, Loder EW. Medication overuse headache: an entrenched idea in need of scrutiny. Neurology 2017;89: 1296-304.

8. Kristoffersen ES, Straand J, Vetvik KG, ym. Brief intervention for medication-overuse headache in primary care. The BIMOH study: a double-blind pragmatic cluster randomised parallel controlled trial. J Neurol Neurosurg Psychiatry 2015;86:505-12.
9. Carlsen LN, Munksgaard SB, Jensen $R H$, ym. Complete detoxification is the most effective treatment of medication-overuse headache: a randomized controlled open-label trial. Cephalalgia 2018;38: 225-36.

10. de Goffau MJ, Klaver ARE, Willemsen MG, ym. The effectiveness of treatments for patients with medication overuse headache: a systematic review and metaanalysis. J Pain 2017;18:615-27.

11. Find NL, Terlizzi R, Munksgaard SB, ym. Medication overuse headache in Europe and Latin America: general demographic and clinical characteristics, referral pathways and national distribution of painkillers in a descriptive, multinational, multicenter study. J Headache Pain 2015;17:20.

12. Lipton RB, Fanning KM, Serrano $D$, ym Ineffective acute treatment of episodic migraine is associated with new-onset chronic migraine. Neurology 2015;84: 688-95.

13. Ashina S, Serrano D, Lipton RB, ym. Depression and risk of transformation of episodic to chronic migraine. J Headache Pain 2012;13:615-24.

14. Bigal ME, Lipton RB. Obesity is a risk factor for transformed migraine but not chronic tension-type headache. Neurology 2006; 25:252-7.

15. Fernandes G, Franco AL, Goncalves DADG, ym. Temporomandibular disorders, sleep bruxism, and primary headaches are mutually associated. J Orofac Pain 2013;27 14-20.
16. May A, Schulte LH. Chronic migraine: risk factors, mechanisms and treatment. Nat Rev Neurol 2016;12:455-64.

17. Ollikainen J. Päänsärkypotilas päivystyspoliklinikassa. Duodecim 2014;130:391-7.

18. Novack V, Fuchs $L$, Lantsberg $L$, ym. Changes in headache frequency in premenopausal obese women with migraine after bariatric surgery: a case series. Cephalalgia 2011;31:1336-42.

19. Pavlovic JM, Vieira JR, Lipton RB, ym. Association between obesity and migraine in women. Curr Pain Headache Rep 2017; 21:41.

20. Diener HC, Bussone G, Van Oene JC, ym. Topiramate reduces headache days in chronic migraine: a randomized, doubleblind, placebo-controlled study. Cephalalgia 2007;27:814-23.

21. Aurora $S K$, Winner $P$, Freeman $M C$, ym. Onabotulinumtoxin $A$ for treatment of chronic migraine: pooled analyses of the 56-week PREEMPT clinical program. Headache 2011;51:1358-73.

22. Pistoia F, Sacco $S$, Carolei A. Behavioral therapy for chronic migraine. Curr Pain Headache Rep 2013;17:304.

23. Yang CP, Chang MH, Liu PE, ym. Acupuncture versus topiramate in chronic migraine prophylaxis: a randomized clinical trial. Cephalalgia 2011;31:1510-21.

24. Edvinsson $L$, Haanes $K A$, Warfvinge $K, y m$. CGRP as the target of new migraine therapies - successful translation from bench to clinic. Nat Rew Neurol 2018;14:338-50.

\section{SUMMARY}

Chronic migraine

Chronic migraine is the rare, nasty and disabling form of migraine. By definition, there are more headache days than headache-free days. Medication overuse is universal and often the major risk factor. On the other hand, ineffective use of acute treatments also increases the risk for chronification of migraine. Cornerstones of the treatment are identification and avoidance of predisposing factors, effective use of preventive medications and avoidance of overuse of acute treatments. All migraine prophylactics can be used, but best evidence is for topiramate and botulinum toxin. Treatment has to be resilient, prolonged and systematic. New migraine-specific treatments are desperately needed, and indeed, targeting the CGRP-pathway seems to be opening a whole new era also in the treatment of chronic migraine. 